\title{
The effects of motor vehicle accidents on careers and the work performance of victims
}

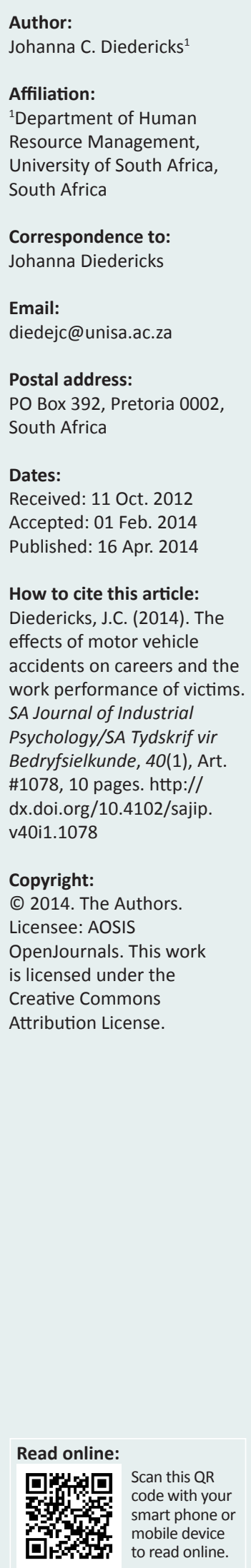

Orientation: Research into the long-term effects of motor accidents on the work performance and careers of victims in South Africa is limited. Results of this research are important for employers who must assist the employees after they return to work.

Research purpose: The purpose of this study was to contribute to research on the effects of the injuries by investigating the relationship between the severity of the injuries and the careers and growth potential of victims.

Motivation for the study: Employers could use the information on the effects of the injuries on the careers of victims to plan interventions and job accommodations to retain employees and to manage their well-being and performance.

Research design, approach and method: The author conducted a quantitative survey on a purposive sample $(N=199)$ of adult victims of motor vehicle accidents in 2010 in South Africa. She used descriptive and inferential statistics to analyse the data.

Main findings: The author observed a number of significant relationships between the effects of the different injuries on the careers and growth potential of victims.

Practical/managerial implications: Organisations and managers need to recognise the physical and psychological effects of injuries victims sustain in motor accidents and the associated responsibility of organisations to accommodate these employees.

Contribution/value-add: The findings of the study can add to the literature and provide insights into the consequences of the injuries. They also provide information that can assist organisations to create an awareness of job accommodation and employee wellness of accident victims.

\section{Introduction \\ Background to the study}

Work and employment are significant parts of the lives of many people. Work contributes to personal status as well as values and maintains health and well-being through meaningful activities and social connections (Fadyl \& McPherson, 2010). Most adults organise their lives around work (Al-Qutop \& Harrim, 2011). In addition, there is increasing evidence of improved health associated with employment, even for people with significant impairments.

Road crashes are leading causes of traumatic injury worldwide. This is also true for South Africa and there is strong evidence that the recovery of road crash victims is poor (Donaldson, Brooke \& Faux, 2009). Road traffic related injuries often result in disability and are a global public concern (Berecki-Gisolf, Collie \& McClure, 2013). Research by Juillard, Labinjo, Kobusingye \& Hyder (2010) shows that injuries resulted in reported disability in $33 \%$ of respondents. The effects of these injuries on the productivity, career development, career progress, income potential, socioeconomic status and often the career choices of the victims is huge and often life changing. According to the World Health Organization ([WHO] 2001), one can subdivide road crash victims into different road traffic crash (RTC) categories: drivers, passengers, motorcyclists, bicyclists, pedestrians and others.

Figures the Road Traffic Management Corporation (RTMC) released in South Africa, as published in the Road Accident Fund annual report (2010), show that the number of accidents with fatalities increased by $0.5 \%$ to 10857 in the 2010 calendar year from 10805 in the previous calendar year. Applying the global standard of an average of 20 injuries for each fatality, the expected number of persons injured on South African roads is approximately 275360 per year.

The road accident fund (RAF) finalised 262185 claims during 2010 and paid out R11.4 billion in claims compared to R4.8bn five years earlier, an increase of 137\% (RTMC annual report, 2010). 
These statistics show the magnitude of the effect of motor vehicle accidents (MVAs) on the South African population and work force. Organisations that want to offer all employees personal growth and development opportunities can no longer ignore the fact that they also have to offer the same opportunities to injured employees when they return to paid employment.

Research that focuses on the long-term effects of MVAs on the lives and work of people in South Africa is limited. The aim of the study, the basis of this article, was to investigate the current situation, as the literature identifies it, and the empirical research that researchers have conducted on the effects of MVAs on the careers and growth potential of the victims as well as how this will affect organisations. It is also important to investigate the accommodation of people in the work environment after MVAs (Hepburn, Franche \& Francis, 2010). By identifying the extent of the injuries victims sustain and how organisations can accommodate this in the work environment, one can make recommendations to improve the working conditions of victims. Early detection and managing psychological and occupational issues can improve the quality of the work lives of victims. Organisations can offer opportunities to advance their careers.

This study can add to the research on one of the most traumatic incidents that can influence the careers and incomes of victims and their effects on their futures. Assessing the consequences of these injuries on employees will yield valuable information to human resource practitioners and industrial psychologists concerned with the well-being of individual employees and, more specifically, the future careers of victims of motor vehicle accidents.

This article consists of four parts. Firstly, it provides an overview of the literature. This describes the important concepts and terminology this study uses. Secondly, it describes the research design, including the research approach and method. The results and a discussion of the findings follow. The article concludes with a synopsis of the main conclusions, the implications for practice and recommendations for future research.

\section{Trends from the research literature}

Industrial psychologists become involved in forensic psychology and personal injury claims that often lead to legal disputes. One can define forensic psychology broadly as applying psychological knowledge to the legal field or as a deeper understanding of human behaviour and human psychological functioning (Roos \& Vorster, 2009). In 2008, third-party claims (motor vehicle accident claims) in the Pretoria High Court made up more than $60 \%$ of all matters scheduled for trial on any given day (Adams \& Adams Attorneys, 2008). According to the annual report of the Road Accident Fund (2010), the number of claims registered in 2008 was 267 133. In 2009, it registered 294771 claims and 209981 claims in 2010. The reason for the decline in claims may be the result of a change in legislation. In all these legal cases, industrial psychologists must assist to quantify the loss of income victims sustained or will sustain in future (Lewis, 2009).

Internationally, industrial psychologists, also known as vocational psychologists or earnings experts, practise in the forensic context. They help to quantify victims' loss of earning capacity (Kaiser, 1986; Lewis, 2009). Whenever people's ability to work, to continue and/or to advance in their present careers is affected or is questionable, it is necessary to determine their loss of earnings, loss of work capacity, future loss of earnings and/or earning potential (Lewis, 2009; Lowenstein, 2002).

Loss of earnings implies the direct loss of income a person sustains because of an occurrence (Lewis, 2009). An example is taking extensive sick leave to recover from physical injuries. Loss of work capacity refers to the loss of ability to do the work one receives training to do (Lewis, 2009). An example is a hairdresser who loses her dominant hand. Future loss of earnings refers to the earnings a person could have earned had it not been for the occurrence (Honey, 1987). Finally, future loss of earning potential refers to people's loss of potential, motivation and ability to adapt to make a success of their careers (Honey, 1987).

In 2001, 495300 Australians reported long-term conditions road crashes caused. The Australian Bureau of Statistics reported that this represented $22 \%$ of long-term sequelae [A condition which is the consequence of a previous disease or injury] from injury. These sequelae included only physical impairments like chronic pain and joint disorders. Although fatality rates from MVAs in Australia have decreased by almost 3\% annually since 1992 (Gargett, Connelly \& Nghiem, 2011), the number of people seriously injured has increased (Henley \& Harrison, 2011). However, the effects of road crashes extend beyond physical and functional disability. They include psychological disorders and a range of social and emotional problems (Donaldson et al., 2009).

Read, Kufera and Dischinger (2004) confirmed that, 12 months after a road crash, $35 \%$ of patients reported continued difficulty walking and $26 \%$ reported continued pain that interfered with the activities of daily life. Furthermore, Read et al. (2004, p. 815) reported that $57 \%$ of patients 'felt the financial impact of their injury was moderate to severe and caused hardships for themselves and their families'. Only $56 \%$ of participants who had employment at the time of the accident were working again after six months. Similarly, Evans, Airey and Cheli, (2003) found, in a follow-up of young road crash victims, that, in the five years following major trauma, $38 \%$ of those who were at school at the time of injury left school with no qualification, whilst $17 \%$ reported that their disability made it impossible to work.

Shults, Jones and Kresnow (2004, p. 450) reported that, after investigating 442 victims who had previously been injured in road crashes, 33\% had difficulty with '...instrumental activities of daily living', which include shopping, preparing 
their own food, managing their personal businesses or even using telephones. A further $49 \%$ reported difficulty with 'functional activities', like walking up 10 steps or reaching over their heads. Of this high burden of disability, Shults et al. (2004) reported that $73 \%$ were associated with orthopaedic impairment or inter-vertebral disc disorders.

Factors that one associates with whether a person returns to paid employment after injuries include severity and type of physical impairments, physical demands of the preinjury occupation, level of education, age at onset of injury and ethnicity (Fadyl \& McPherson, 2010). Often there is a considerable time delay before the injured person returns to work. Furthermore, according to Fadyl and McPherson (2009), the cost of being off work to the victims and their families, in terms of reduced physical, social and psychological wellbeing, is often considerable. Organisations also often report the high cost effects of the absenteeism of these employees (Gargett et al., 2011; Juillard et al., 2010).

Butler, Baldwin and Johnson (2006) reported that workplace accommodations reduce initial periods of work absence by between $30 \%$ and $45 \%$. Other research found that workplace accommodations also reduce absenteeism from work places after a return to work and often lead to a longer work relationship with organisations (Burkhauser, Butler \& Kim, 1995; Butler et al., 2006).

From the available literature on medico-legal claims and from an industrial psychology perspective, it is clear that the effects of motor vehicle accidents on victims can vary. They vary from slight effects on performance, where employees will still be able to reach their expected career ceilings, to significant effects on performance where employees may not reach their expected career ceilings. In worst-case scenarios, employees may become functionally unemployable or even have to take early retirement. The severity of the effect of a MVA on the career of victims became clear from a discussion of previous studies.

\section{Current theoretical perspectives}

MVAs are likely to result in high-impact injuries, like whiplash injuries that do not necessarily require hospitalisation but can result in extensive work disability (Berecki-Gisolf et al., 2013). Work disability has major economic effects. It relates to health because good health is a requirement for employment. It also relates to causation because employment benefits health (Rueda et al., 2012).

When one investigates the influence of injuries on the careers of victims and on organisations, one needs to clarify the concepts of disability.

\section{Permanent partial disability}

When one identifies permanent partial disability (PPD), it is important to differentiate between three concepts: impairment, functional limitations and disability. People often use them interchangeably but they are not synonymous (Butler, Baldwin \& Johnson, 2006).
Impairment is an anatomical or physiological abnormality or loss associated with an illness or injury, whilst functional limitations are restrictions of cognitive, physical or sensory capacities that may result from impairment (Butler et al., 2006).

A work disability occurs when functional limitations restrict workers' ability to perform the tasks required in the jobs for which the workers are qualified by education and experience (Nagi, 1969). The professional position of the employees before the accidents can be decisive (Lange, Burgmer, Braunheim \& Heuft, 2007). Their research also indicates that labourers have higher risks of poorer occupational reintegration after accidents. The reasons may be, according to Bruyns, Jaquet and Schreiders, (2003), that these workers depend on physical integrity in their jobs and, because of their skills and training, they are usually not in a position to choose alternative jobs. The South African cabinet defined PPD as the permanent or temporary restriction or limitation of a person from participating in activities or everyday life. This can show physical, sensory, psychological, developmental, learning or neurological impairments (Palama, 2010).

The United Nations (UN) Convention on Rights of Persons with Disabilities (2008) defines people with disabilities as:

those who have long term physical, mental, intellectual or sensory impairments which, in interaction with various barriers, may hinder their full and effective participation in society on equal basis with others.

This can mean a discontinuation of the course of life and work.

Tate and Pledger (2003) looked at disability as a complex concept that can vary over time and includes the environment, society, personality as well as psychological factors of the victim. According to Lange et al. (2007), the psychosocial effects of MVAs do not necessarily connect to the objective severity of the accident and injuries.

In South Africa, the Employment Equity Act (Act 55 of 1998) defines people with disabilities, physical or mental impairments as people who will experience limitations in progression in the work environment or even find it difficult to enter the world of work. For the purpose of this study, the author identified these categories of impairment: orthopaedic and limb pathology, spinal cord or neck injuries, neurological injuries, cognitive disabilities and psychological disorders.

\section{Orthopaedic and limb pathology}

This includes different physical disabilities, which could be the result of motor vehicle accidents. Examples are losing limbs, pelvic fractures and chest injuries. They can limit physical activities and mobility, result in chronic pain and discomfort and can cause employees to be less productive or, in severe cases, not to participate in work activities at all. According to a study by Ratzon, Ari, Froom, Friedman and Amit (2013), MVA-related pelvic fractures are significant 
causes of functional limitations and disability. They result in high costs.

\section{Spinal cord or neck injuries}

Neck and spinal cord injury (SCI) can sometimes lead to lifelong disabilities and can impair mobility temporarily or permanently (Fadyl \& McPherson, 2010). This kind of injury occurs mostly in severe accidents. In an incomplete injury, the messages the spinal cord conveys are not completely lost and employees can continue work activities, although often of a different nature. Employers need to provide support and suitable working conditions and rehabilitation (Vogel, Barker, Young, Ruseckaite \& Collie, 2011). A complete injury often results in people becoming paralysed and not able to continue with their pre-accident career (Fadyl \& McPherson, 2010). They emphasise that research has consistently shown that many people with spinal cord injuries do not return to work at all.

\section{Neurological injuries}

According to Disabled World (2011), disability of the brain will occur because of a brain injury, which can range from mild to moderate to severe. It identifies two types of brain injuries: acquired brain injuries (ABI) (not hereditary and various external forces can cause them) and traumatic brain injury (TBI) (which refers to emotional dysfunction or disturbed behaviour and can be hereditary).

Traumatic brain injuries can have severe limiting and disturbing effects on the people suffering from them (Vargo \& Young, 2011) and will definitely affect their work performance negatively. According to their research, they can include disturbed cognition, communication, physical health, behaviour, personality and mood or indirectly limit other aspects of life.

\section{Cognitive disabilities}

Vargo and Young (2011) argue that learning disabilities refer to different specific learning manifestations that relate to people's intrinsic ability to learn, but which environmental factors do not cause. People who experienced severe accidents may acquire these disabilities because of brain or head injuries. Examples of learning disabilities include specific learning difficulties in basic reading (word identification or decoding), reading fluency skills, reading comprehension, writing, mathematics calculation, mathematics problem solving, listening (listening comprehension), speaking (oral expression), reasoning, learning and memory (Vargo \& Young, 2011).

It is clear that employees, who have sustained head or brain injuries and who suffer from one or more of these symptoms may find it difficult to continue functioning in a demanding work environment where cognitive reasoning is a requirement.

\section{Psychological disorders}

Post-traumatic stress disorder: Read et al. (2004) reported post-traumatic stress disorder (PTSD) in about $50 \%$ of pa- tients six months after injury. Psychological morbidity was especially evident in those not returning to work after one year (Berna, Vaiva, Ducrocq, Duhem \& Nandrino, 2012). PTSD also affects problem-solving abilities, abstract reasoning, planning, organisation, setting goals, creativity, selfcontrol and other behavioural aspects necessary for optimal functioning (Read et al., 2004).

One commonly associates certain psychological conditions with particular occupational profiles. Research shows a high level of stress, for example, in the more artistic occupations (Lowman, 1997).

The interaction of mental health with career concerns is not a new field of study. Some authors, like Spokane (1989), have argued that career and mental health issues are unrelated in general, whereas others (Blustein, 1987, 1992; Brown \& Brooks, 1985; Herr, 1989; Loughead, Black \& DeLucia, 1989; Lowman, 1997; Spengler, Blustein \& Strohmer, 1990) have argued that there is an integral and complex overlap between mental health and career well-being.

The relationship between depression and career problems (deLisio, 1986; Evans, Cloitre, Kocsis \& Keitner, 1996) is significant. People who experience career-related concerns usually experience depression. Their research emphasises that employees who cannot function optimally in a work environment after injuries are likely to experience depression or psychological morbidity.

In the context of this study, the author could not determine the extent of trauma in the respondents because it was outside the field of this research. However, the loss of employees' work capacity or the ability to do the work they received training to do is important. PTSD appears to have a steep spontaneous remission curve during the first year after an accident. However, at least $10 \%$ of trauma-exposed people suffer chronic distress (Koch, Douglas \& O’Neill, 2005).

PTSD is just one of several potential mental injuries that could appear after trauma, like motor vehicle accidents. PTSD or any other psychological disorder generally increases absence from work (Lange et al., 2007). The importance for legal purposes, and more specifically for forensic psychologists, is that any emotional state, like anxiety, fear or other negative emotions, cause harm and interfere with daily functioning. It influences the optimal functioning of employees in work environments. Therefore, compensation for loss of income in legal claims is appropriate. One considers them when preparing these legal claims.

Research has shown that women have a greater risk of PTSD from motor vehicle accidents (Douglas \& Koch, 2000; Koch, Douglas, Nicholls \& O'Neill, 2005) than men have (Berna et al., 2012). The greater incidence of PTSD in women may be part of the more general phenomenon in which women display more psychological distress than men, irrespective of their exposure to traumatic stressors (Almeida \& Kessler, 1998). MVAs are unexpected traumatic events. Research 
that Fullerton et al. (2001) conducted found that the risk for women of experiencing PTSD after a MVA is 4.64 times greater than it is for men. Tolin and Foa (2006) found that the prevalence of PSTD in woman was twice as much as it was in men. These authors suggest that men have a tendency to develop drug or alcohol abuse behaviour after the trauma. Women supposedly develop more anxious, depressive and somatic disorders.

One may consider that victims, after a traumatic accident, have a larger number of severe symptoms or higher scores on continuous measures of psychological distress and experience long-term consequences in the work environment. Post-traumatic stress correlates with impairment in social, financial, physical and psychological functioning (Amaya-Jackson, Davidson, Hughes, Swartz \& Reynoldts, 1999; McCarren et al., 1995). It seems that high levels of PTSD and depressive symptoms place employees at risk of work disability. However, social or interpersonal factors like hostility and social isolation, perceived or actual low support from employers and work or life dissatisfaction in general are all variables that may influence employees' ability to work productively after serious motor vehicle accidents (Lange et al., 2007). When they assess the loss of income of these employees, forensic psychologists can assert with some confidence that PTSD places the employees at risk of work-related disability. However, they must acknowledge that other variables play a role in disability claims. Psychologists need to do an idiographic behavioural analysis of the characteristics of individual PTSD claimants that make them more or less vulnerable to work-related disability (Koch et al., 2005).

The author used the literature review to formulate two research hypotheses for investigating the extent of the effect of a MVA on employees' careers:

Hypothesis 1: There is a statistically significant positive relationship between the severity of injuries employees sustain in motor vehicle accidents and their performance, careers and growth potential.

Hypothesis 0: There is no statistically significant positive relationship between the severity of injuries employees sustain in motor vehicle accidents and their performance, careers and growth potential.

\section{Research objective}

The present study aimed to assess how the severity of motor vehicle accidents influence the career and growth potential of employees. The author posed this research question:

'What is the statistical nature of the relationship between the severity of injuries employees sustain in MVAs and the performance, career and growth potential of employees in a sample of MVA victims in South Africa?'

\section{The potential value of the study}

Assessing the relationship between the severity of injuries victims sustain in MVAs and their influence on the careers and growth potential of the victims could provide valuable information that managers, industrial psychologists and human resource practitioners can use to accommodate these victims in work environments. One can make recommendations for improving the working conditions of these victims. In addition, the research could add new knowledge.

\section{Research design Research approach}

For this study, the author used a purposive survey design to achieve the research objective (Shaughnessy \& Zechmeister, 2003).

\section{Research method \\ Participants and sampling}

The author selected a purposive sample of 199 adults from respondents, who were involved in motor vehicle accidents in 2010 and who were claiming loss of income from the Road Accident Fund, for this study. The rationale for choosing this approach rests upon acquiring interesting information from the victims of MVAs in a relatively small sample.

In terms of current legislation, claimants need to have suffered $27 \%$ whole person impairment in order to claim for loss of income. Legislation also provides for an appropriately qualified expert to decide that the plaintiff sustained a serious injury. This requires quantifying claims by applying the official Narrative Test. Not all 199 claimants have reached Maximal Medical Improvement (MMI). However, the experts have decided that, after reaching MMI, all the claimants will qualify as having sustained serious injuries.

The study population consisted of $72 \%$ male and $28 \%$ female participants. Ethnicity was not a criterion in this study. Therefore, the author did not separate the participants into different ethnic groups. The ages of the participants ranged from 20-69. Most of the participants (53\%) were younger than 40 when their accidents occurred. The author made no distinction between the hierarchical or education levels of the claimants for the purposes of this study.

\section{Measuring instrument}

The research instrument consisted of open-ended questions. The collection of data focused on six main areas of interest: biographical details, age of the respondent when the accident occurred, the current employment status of the respondent, the level of employment of the respondent at the time of the accident and the injuries the respondent sustained in the accident.

The author categorised the effects of the accident on the career of the respondent as a slight influence on career and earnings; significant influence on career and earnings; early retirement; and functionally unemployable. The author, an industrial psychologist and labour market expert, determined this using the findings of the medical experts about the claimants' residual pathology. 
The author could categorise the current employment status of the respondents from the results as unemployed, self-employed or salaried and the level of employment as unskilled, semi-skilled, artisan or professional.

Occupational therapists and the industrial psychologist obtained collateral information by considering the content of the claimants' jobs, in terms of pre- and post-accident work performance, and their career and earnings progress. The author obtained information on socioeconomic factors like poor or advanced environments, political factors like employment equity and employment in rural areas as opposed to urban areas.

Medico-legal specialists and expert reports confirmed the information in the questionnaire in all cases. To ensure the content validity of the measurement instrument, other experts, who are also involved in road accident claims, evaluated it.

\section{Research procedure}

The author gave the respondents information about the aim of the questionnaire, how she would use the data and guaranteed the confidentiality of the information. Participation in this study was voluntary and the author treated all information anonymously and with a high regard for the respondents' confidentiality. The author converted the raw data by using the IBM SPSS statistics version 19 for further analysis.

\section{Statistical analysis}

The data analysis procedure the author chose for this research used the applicability of the data to the empirical nature of the research design as its basis. She used descriptive and inferential statistics to analyse the measurements.

The author identified a characteristic for each experimental unit (Wackerly, Mendenhall \& Scheaffer, 2008). She used the Pearson chi-square test to determine how well theoretical distributions fit the empirical distributions she obtained from sample data (Spiegel \& Lindstrom, 2000). She used the Pearson chi-square test to assess two types of comparisons: tests of goodness of fit and tests of independence. A test of goodness of fit establishes whether an observed frequency distribution differs from a theoretical one. A test of independence assesses whether paired observations on two variables, expressed in a contingency table, are independent of each other. One usually interprets a chi-square probability of 0.05 or less as justification for rejecting a null hypothesis that the two variables are unrelated. One then accepts the alternate hypothesis that the variables have a relationship (Spiegel \& Lindstrom, 2000).

\section{Results}

The author used descriptive statistics, chi-square tests, correlations, frequencies and cross tabulations for all the constructs that she measured.
Table $1 \mathrm{a}$ and Table $1 \mathrm{~b}$ give the cross tabulations between the ages of the participants and the influence of motor vehicle accidents on the careers and performance of the participants.

The influence of motor vehicle accidents on the performance and careers of younger victims was significantly higher (75\%) than was the influence on older victims (25\%). This may result in younger victims experiencing a slower than expected income growth and they may not reach their expected career ceiling as soon as they had hoped before their accidents.

The influence on early retirement (58.3\%) and the probability for victims to become functionally unemployable (57.9\%) seemed more likely when the victims were older than 40 .

The Pearson chi-square measured 17.125 with an observed probability of 0.009 . When one looks at the $95 \%$ level of significance, the probability is 0.009 , which is smaller than $5 \%(p<0.05)$. This means that the author rejected the null hypothesis at the $95 \%$ level of significance.

Because of the rejection of the null hypothesis, this test shows that there is a significant correlation between the age

TABLE 1a: The cross tabulation of ages and their influence on performance and careers.

\begin{tabular}{lcc}
\hline Influence on performance and careers & \multicolumn{2}{c}{ Age } \\
\cline { 2 - 3 } & Under 40 (\%) & Above 40 (\%) \\
\hline Slight influence on performance & 65.8 & 34.2 \\
Significant influence on performance & 75.0 & 25.0 \\
Early retirement & 41.7 & 58.3 \\
Functionally unemployable & 42.1 & 57.9 \\
\hline
\end{tabular}

TABLE 1b: Correlations between age and influence on careers as in Table 1a.

\begin{tabular}{lccc}
\hline Statistical test & Value & $d f$ & $\begin{array}{c}\text { Asymp. Sig. } \\
\text { (2-sided) }\end{array}$ \\
\hline Pearson chi-square & $17.125 \dagger$ & 6 & 0.009 \\
Likelihood ratio & 17.988 & 6 & 0.006 \\
Linear-by-linear association & 3.166 & 1 & 0.075 \\
$N$ of valid cases & 199 & - & - \\
\hline
\end{tabular}

Asymp. Sig., asymptotic significance.

$\dagger, 5$ cells $(35.7 \%)$ have an expected count of less than 5 . The minimum expected count is 0.37 .

TABLE 2a: The cross tabulation of level of functioning of workers when accidents occur and their influence on performance and careers.

\begin{tabular}{lcccc}
\hline \multirow{2}{*}{$\begin{array}{l}\text { Influence on performance } \\
\text { and careers }\end{array}$} & \multicolumn{4}{c}{ Level of worker (\%) } \\
\cline { 2 - 5 } & Unskilled & Semi-skilled & Artisan & Professional \\
\hline Slight influence on performance & 7.9 & 65.8 & 13.2 & 13.2 \\
Significant influence on performance & 18.4 & 61.8 & 5.3 & 14.5 \\
Early retirement & 8.3 & 58.3 & 16.7 & 16.7 \\
Functionally unemployable & 68.4 & 26.3 & 2.6 & 2.6 \\
\hline
\end{tabular}

TABLE 2b: Correlation between level of functioning and influence on performance and careers as in Table 2a.

\begin{tabular}{lccc}
\hline Statistical test & Value & $d f$ & $\begin{array}{c}\text { Asymp. Sig. } \\
\text { (2-sided) }\end{array}$ \\
\hline Pearson chi-square & $57.253 \dagger$ & 18 & 0.000 \\
Likelihood ratio & 53.049 & 18 & 0.000 \\
Linear-by-linear association & 3.442 & 1 & 0.064 \\
$N$ of valid cases & 199 & - & - \\
\hline
\end{tabular}

Asymp. Sig., asymptotic significance.

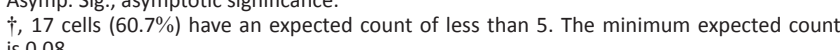
is 0.08 . 
of the respondents and the influence on the performance and careers of victims of MVAs. Younger participants showed a higher percentage of injury pathology on all the categories the author measured than did the participants older than 40. Statistics on MVAs in industrialised countries show that young drivers are a particularly vulnerable group (Hasselberg \& Laflamme, 2003) and MVAs are the most common causes of death amongst young adults. They could also be one of the major contributors to socioeconomic differentials in mortality and morbidity.

Table $2 \mathrm{a}$ and Table $2 \mathrm{~b}$ give the cross tabulations between the levels on which participants functioned at the time of their accidents and the influence on their performance and careers.

If one considers that $65.8 \%$ of semi-skilled participants reported a slight influence on their careers, $61.8 \%$ a significant influence and $58.3 \%$ early retirement because of their injuries, one could argue that motor vehicle accidents have a huge influence on the careers and earnings of semiskilled workers.

The Pearson chi-square measured 57.253 with an observed probability of 0.000 . When one looks at the $95 \%$ level of significance, the probability is 0.000 , which is smaller than $5 \%(p<0.05)$. This means that the author rejected the null hypothesis at the $95 \%$ level of significance.

Because of the rejection of the null hypothesis, these results showed that there was a significant correlation between the level at which the participants functioned at the time of their accidents and their effects on the employability of the participants.

Hasselberg and Laflamme (2003) highlight clear socioeconomic differences in MVAs between younger car drivers and show that those from an unskilled, self-employed or basic educational background in particular have a greater risk of injury. The findings suggest that unskilled or semiskilled workers often experience effects on their careers and income potential that are more significant.

Table $3 \mathrm{a}$ and Table $3 \mathrm{~b}$ give the cross tabulation between the educational level of respondents and the influence of MVAs on the performance and careers of victims.

Table $3 a$ and Table $3 b$ show that the highest significant influences on the career of victims seemed to be in the group of people with secondary or tertiary qualifications. The influence on performance and careers varied from a slight influence, a slower than expected growth in income or a more significant influence. This meant that victims did not reach their expected career ceilings or were even functionally unemployable. Victims with primary, secondary and tertiary schooling were prone to early retirement.

The Pearson chi-square measured 105.491 with an observed probability of 0.000 . When one looks at the $95 \%$ level of significance, the probability was 0.000 and was larger than
TABLE 3a: Cross tabulation of education level and the influence of motor vehicle accidents on the performance and careers of victims.

\begin{tabular}{lcccc}
\hline \multirow{2}{*}{$\begin{array}{l}\text { Influence on performance } \\
\text { and career }\end{array}$} & Education level (\%) \\
\cline { 2 - 5 } & No schooling & Primary & Secondary & Tertiary \\
\hline Slight influence on performance & 0 & 0 & 36.9 & 63.1 \\
Significant influence on performance & 0 & 6.6 & 50 & 43.4 \\
Early retirement & 0 & 41.7 & 16.7 & 41.6 \\
Functionally unemployable & 18.4 & 26.3 & 39.5 & 15.8 \\
\hline
\end{tabular}

TABLE 3b: Correlation between educational level and influence on performance and career as in Table 3a.

\begin{tabular}{lccc}
\hline Statistical test & Value & $d f$ & $\begin{array}{c}\text { Asymp. Sig. } \\
\text { (2-sided) }\end{array}$ \\
\hline Pearson chi-square & $105.491 \dagger$ & 54 & 0.000 \\
Likelihood ratio & 99.428 & 54 & 0.000 \\
Linear-by-linear association & 13.680 & 1 & 0.000 \\
$N$ of valid cases & 199 & - & - \\
\hline
\end{tabular}

Asymp. Sig., asymptotic significance.

$\dagger, 58$ cells $(82.9 \%)$ have an expected count of less than 5 . The minimum expected count is 0.04 .

$5 \%(p<0.05)$. This meant that the author rejected the null hypothesis at the $95 \%$ level of significance.

This test indicated to the author that there was a significant correlation between the education level of the participants and the influence of accidents on their performance and careers. According to Lange et al. (2007), labourers or people with no schooling evaluated their injuries and their effects as more severe. They demonstrated more anxiety about the work-related consequences than did victims with higher education levels. It is interesting to observe that $18.4 \%$ of the victims with no schooling were functionally unemployable after their accidents compared to $15.8 \%$ of the victims with tertiary levels of education. Victims with lower levels of education had a 4.3 fold higher risk of poorer occupational reintegration after a MVA (Lange et al., 2007), firstly because they depend on physical integrity in their work activities and secondly because they are not in a position to choose alternative jobs.

Table $4 \mathrm{a}$ and Table $4 \mathrm{~b}$ gives the cross tabulation between the types of injuries the respondents sustained in MVAs and their effects on performance and careers.

Table $4 \mathrm{a}$ and Table $4 \mathrm{~b}$ show that the most injuries, which resulted in a slight effect on work performance, on careers or caused victims to become functionally unemployed, were orthopaedic injuries. This correlates directly with the research of Schults, Jones and Kresnow (2004). It indicated that 73\% of road crash-related physical disability is associated with orthopaedic impairment or intervertebral disc disorders.

The Pearson chi-square measured 105.491 with an observed probability of 0.000 . At the $95 \%$ level of significance the probability is 0.000 , which is smaller than $5 \%(p<0.05)$. This meant that the author rejected the null hypothesis at the $95 \%$ level of significance.

Because of the rejection of the null hypothesis, these results show that there was a significant correlation between the types of injuries victims sustained in MVAs and their effects 
TABLE 4a: Cross tabulation of type of injuries victims sustained and their influence on careers and performance.

\begin{tabular}{lcccc}
\hline Effect & & \multicolumn{2}{c}{ Injury (\%) } \\
\cline { 2 - 6 } & Cognitive & Neurological & Orthopaedic & Psychological \\
\hline Slight effect on performance & 2.6 & 0 & 60.5 & Scars (\%) \\
Significant effect on performance & 1.3 & 5.3 & 53.9 & 10.5 \\
Early retirement & 0 & 0 & 58.3 & 2.6 \\
Functionally unemployable & 5.3 & 13.2 & 52.6 & 0 \\
\hline
\end{tabular}

TABLE 4b: Correlation between type of injuries and their influence on careers and performance as in Table 4a.

\begin{tabular}{lccc}
\hline Statistical & Value & $d f$ & $\begin{array}{c}\text { Asymp. Sig. } \\
\text { (2-sided) }\end{array}$ \\
\hline Pearson chi-square & $105.491 \dagger$ & 54 & 0.000 \\
Likelihood ratio & 99.428 & 54 & 0.000 \\
Linear-by-linear association & 13.680 & 1 & 0.000 \\
$N$ of valid cases & 199 & - & - \\
\hline
\end{tabular}

Asymp. Sig., asymptotic significance.

$\dagger, 58$ cells $(82.9 \%)$ have an expected count of less than 5 . The minimum expected count is 0.04 .

on their employability. As this study showed earlier, limb and orthopaedic disability can limit physical mobility. According to Ratzon et al. (2013), most victims reported that their work capacity post-injury was lower than their jobs required. Pelvic injuries often result in below-range functional performance.

Functional limitations are any restrictions of cognitive, physical or sensory capacities that could result from impairment (Butler et al., 2006). Cognitive and neurological injuries often result in victims becoming functionally unemployable and not able to pursue their careers.

\section{Discussion}

This study was a forensic investigation into the effects of the injuries victims sustained, in motor vehicle accidents, on their careers and future growth potential in different age groups and at different levels in the labour market.

The author categorised injuries to determine the extent of the influence of the injuries on victims. The results showed that people injured in MVAs in South Africa, who have to return to work after the accidents, experience long-term medical and psychosocial consequences. Their employers offer little management of these consequences and often no workplace accommodation. The overall results showed that employers must become more familiar with their employees and their health conditions, which deplete company resources and potential profits, as previous research (Miller, 2009) showed.

The statistical analyses yielded a number of significant correlations between the variables of concern to this study. The analyses emphasised the extent of the traumatic consequences of accidents on the victims. The high percentages of severe consequences emphasise the importance of the concerns. The high percentage of victims in the below 40 age category, who were experiencing a significant influence on career development and therefore a slower than expected growth in income, was a concern. It would have short-term consequences for organisations. Furthermore, if this trend continues, they would definitely also have long-term consequences for victims. These results are consistent with the findings of Ivers, Senserrick, Boufous and Stevenson (2009). Their results showed that younger drivers are associated with risky driving, high-levels of speed and have increased risks of crashing.

Hasselberg and Laflamme (2003) found that young people in higher socioeconomic groups experienced almost 25\% fewer MVA injuries than those in lower socioeconomic groups. Young people with highly educated parents also experience fewer MVA injuries than do young people with uneducated parents. The long-term effects of parental social class and education on MVAs are evident in the case of young drivers. The findings of the present study, about the correlation between the effects of MVAs on semi-skilled victims, seem to corroborate the findings of the study of Hasselberg and Laflamme (2003).

It is interesting to note that such a high percentage of victims with orthopaedic injuries are functionally unemployable. This correlates with the research of Schults et al. (2004). This showed that orthopaedic disc disorders contributed to $73 \%$ of crash-related disability.

The findings suggest that the influence of MVAs on the careers of victims with secondary or tertiary qualifications could be higher than that in the group of victims with primary education or no schooling at all. General and specific human capital increase workers' job mobility and determine workers' productivity in the labour market (Butler et al., 2006). Therefore, one may attribute these findings to the fact that the recovery of MVA victims is poor. This could lead to long-term conditions (Donaldson et al., 2009) and difficulty in finding alternative employment after disability because of MVAs.

The effects of the injuries victims sustained in this study seem to be consistent with the findings of Lange et al. (2007). They found that accident related injuries might mean discontinuing the course of life as well as the occurrence of psychological problems. However, other factors could influence the decision to pursue a career. Examples are ability to do the work, pressures, access to suitable jobs and attractive benefits (Fadyl \& McPherson, 2010).

The limited financial resources available for employee assistance or return-to-work programmes in organisations and a lack of awareness of the influence of motor vehicle accidents on victims often result in organisations not assisting these people. Employee maintenance and wellbeing programmes must become part of the forward thinking of organisations. 


\section{Implications for practice}

Organisations need to consider workplace accommodations, like changes to work environments or modifications of job requirements, such as flexible schedules, lighter work or tasks and special training that can compensate for the functional limitations associated with permanent impairments. They will reduce post-injury productivity losses (Butler et al., 2006)

Employment stability is a critical factor in reducing postinjury productivity losses, particularly as time passes after the injury date. Many organisations in industrialised countries developed and implemented return-to-work programmes in order to assist employees with recovery time after injuries (Soklaridis, Cassidy, van der Velde, Tompa \& Hogg-Johnson, 2012). People commonly believe that a return to work marks a recovery from the disabling effects of occupational injuries and an end to the economic losses associated with them. However, Butler et al. (2006) found large productivity losses for injured workers and that many injured workers, who initially return to work, experience significant periods of work absence.

People widely accept that the longer injured workers are away from the workplace, the greater the psychosocial effect and the greater the fear that other employees could replace them. Regular workplace visits or rehabilitation visits could have positive psychological effects on injured workers. Workplace accommodations can improve working relationships with organisations and reduce absenteeism.

Organisations should focus on psychological assistance, flexible schedules, temporary adjustments to tasks or special training programmes. Organisations should address posttraumatic depression and employees should experience well-being through meaningful activities and assistance programmes. It remains important to assist victims whose psychological well-being is affected.

\section{Methodological limitations and future directions in research}

Because the present study was small and limited to participants predominantly in a specific province in South Africa, one cannot generalise the findings to the country as a whole. However, one could generalise the findings to various workplace settings. Furthermore, this study cannot indicate the extent of the trauma the respondents experienced and the author did not investigate injury related job changes.

Although the sample was representative and provided evidence of a serious matter, researchers need to replicate these findings with broader samples in all provinces in South Africa.

The author also recommends that researchers include prospective designs to evaluate the long-term effects of injuries on work performance and on victims.
This study should stimulate further research, especially empirical research that can extend beyond the scope of this study.

\section{Conclusion}

This research study provides a possible insightful understanding of the influence of MVAs on the careers of victims. It has not been explored comprehensively to date and therefore this could provide a basis for future research into interventions and return-to-work programmes in organisations in South Africa.

Furthermore, the psychosocial impact of injury pathology on younger victims and the influence thereof on their career development, socioeconomic status and career choices, deserve more attention.

\section{Acknowledgements Competing interests}

The author declares that no financial or personal relationship(s) influenced her when she wrote this article.

\section{References}

Adams \& Adams Attorneys. (2008). R22 million settlement for motor vehicle accident. Retrieved September 5, 2011, from http://www.adamsadams.com

Almeida, D.M., \& Kessler, R.C. (1998). Everyday stressors and gender differences in daily distress. Journal of Personality and Social Psychology, 75, 670-680. http:// dx.doi.org/10.1023/A:1024781504756, PMid:10646189

Amaya-Jackson, L., Davidson, J.R. Hughes, D.C., Swartz, \& M., Reynoldts. (1999). Functional impairment and utilisation of services associated with post traumatic stress in the community. Journal of Traumatic Stress, 12, 709-724.

Al-Qutop, M.Y., \& Harrim, H. (2011). Quality of worklife human well-being linkage: integrated conceptual framework. International Journal of Business Management, $6,193$.

Australian Bureau of Statistics. (2001). National Health Survey: Injuries, Australia Canberra: ABS, 2001. (ABS Cat. No. 4384. O.)

Berecki-Gisolf, J., Collie, A., \& McClure, R. (2013). Work disability after road traffic injury in a mixed population with and without hospitalisation. Accident Analysis and Prevention, 51, 129-134. http://dx.doi.org/10.1016/j.aap.2012.11.010, PMid:23220006

Berna, G., Vaiva, G., Ducrocq, F., Duhem, S., \& Nandrino, J.L. (2012). Categorical and dimensional study of the predictive factors of the development of a psychotrauma in victims of car accidents. Journal of Anxiety Disorders, 26, 239-245. http:// dx.doi.org/10.1016/j.janxdis.2011.11.011, PMid:22177942

Blustein, D.L. (1987). Integrating career counselling and psychotherapy: A comprehensive treatment strategy. Psychotherapy, 24, 794-799. http://dx.doi. org/10.1037/h0085781

Blustein, D.L. (1992). Towards the reinvigoration of the vocational realm of counseling psychology. Counseling Psychologist, 20, 712-723. http://dx.doi. org/10.1177/0011000092204013

Brown, D., \& Brooks, L. (1985). Career counselling as a mental health intervention. Professional Psychology: Research and Practice, 16, 860-867. http://dx.doi. org/10.1037/0735-7028.16.6.860

Bruyns, C.N.P., Jaquet, J.B., \& Schreiders, T.A.R., (2003). Predictors for return to work in patients with median and ulnar nerve injuries. Journal of Hand Surgery, 28 28-34. http://dx.doi.org/10.1053/jhsu.2003.50026, PMid:12563634

Burkhauser, R.V., Butler, J.S., \& Kim, Y.W. (1995). The importance of employer accommodation on the job duration of workers with disabilities: A hazard model approach. Labour Economics, 2, 109-130. http://dx.doi.org/10.1016/0927 5371(95)80049-4

Butler, R.J., Baldwin, M.L., \& Johnson, W.G. (2006). The effects of occupational injuries after returns to work: work absences and losses of on-the-job productivity. after returns to work: work absences and losses of on-the-job productivity.
Journal of Risk and Insurance, 73, 309-326. http://dx.doi.org/10.1111/j.15396975.2006.00177.x

deLisio, G. (1986) Impairment of work and leisure in depressed outpatients: A preliminary communication. Journal of Affective Disorders, 10, 79-84. http:// dx.doi.org/10.1016/0165-0327(86)90029-7

Disabled World. (2011). Definition of disabilities. Retrieved May 2, 2012, from http:// www.disabled-world.com/disability/types/

Donaldson, L.H., Brooke, K., \& Faux, S.G. (2009). Orthopaedic trauma from road crashes: Is enough being done? Australian Health Review, 33, 72-84. http:// dx.doi.org/10.1071/AH090072, PMid:19203336 
Douglas, K.S., \& Koch, W.J., (2000). Posttraumatic Stress Disorder arising from motor vehicle accidents: A critical review of predictive factors. (Working paper for the Insurance Corporation of British Columbia)

Evans, S.A., Airey, M.C., \& Cheli, S.M. (2003). Disability in young adults following major trauma: 5 Year follow up of survivors. BMC Public Health, 27, 8. http://dx.doi. org/10.1186/1471-2458-3-8, PMCid:PMC149229

Evans, S.A., Cloitre, M., Kocsis, J.H., \& Keitner, G.I. (1996). Social-vocational adjustment in unipolar mood disorders: Results of the DSM-IV field trial. Journal of Affective Disorders, 38, 73-80. http://dx.doi.org/10.1016/0165-0327(95)00045-3, PMid:19806438

Fadyl, J.K., \& McPherson, K.M. (2010). Understanding decisions about work after spinal cord injury. Journal of Occupational Rehabilitation, 20, 69-80. http:// dx.doi.org/10.1007/s10926-009-9204-1, PMid:19806438

Fullerton, C.S., Ursano, R.J., Epstein, M.D., Crowley, B., Vance, K., Kao, et al. (2001). Gender differences in Posttraumatic Stress Disorder After Motor Vehicle Accidents. American Journal of Psychiatry, 158, 9. http://dx.doi.org/10.1176/ appi.ajp.158.9.1486

Gargett, S., Connelly, L.B., \& Nghiem, S. (2011). Are we there yet? Australian road safety targets and road traffic crash fatalities. BMC Public Health, 11, 270. http:// dx.doi.org/10.1186/1471-2458-11-270, PMid:21527042

Hasselberg, M., \& Laflamme, L. (2003). Socioeconomic background and Road traffic injuries: A study of young car drivers in Sweden. Traffic Injury Prevention, 4(3), 249-254. http://dx.doi.org/10.1080/15389580309882, PMid:14522649

Hepburn, C.G., Franche, R.L., \& Francis, L. (2010). Successful return to work: the role of fairness and workplace-based strategies. International Journal of Workplace Health Management, 3(1), 7-24. http://dx.doi.org/10.1108/17538351011031902

Henley, G., \& Harrison, J. (2011). Trends in serious injury due to land transport accidents. In AlHW (Ed.). Injury Research and Statistics Series no 56 Cat. No. INJCAT 132. AlHW. Canberra.

Herr, E.L. (1989). Career development and mental health. Journal of Career Development, 16, 5-18. http://dx.doi.org/10.1177/089484538901600102

Honey, D.P. (1987). MVA practice under act 84 of 1986. Pretoria: Government Printers.

Ivers, R., Senserrick, T., Boufous, S., \& Stevenson. (2009). Novice Drivers' Risky Driving Behaviour, Risk Perception and Crash Risk: Findings From The DRIVE Study. American Journal of Public Health, 99 (9), 1638-1645. http://dx.doi.org/10.2105/ American Journal of

Juillard, C., Labinjo, M., Kobusingye, O., \& Hyder, A.A. (2010). Socioeconomic impact of road traffic injuries in West Africa: exploratory data from Nigeria. Injury Prevention, 16, 389-392. http://dx.doi.org/10.1136/ip.2009.025825

Kaiser, R.S. (1986). Forensic vocational assessment psychology. In M.I. Kurke, \& R G Meyer (Eds), Psychology in product liability and personal injury litigation (pp. 185-206). Washington: Hemisphere.

Koch, W.J., Douglas, K.S., \& O'Neill, M. (2005). Empirical limits for the forensic assessment of PTSD litigants. Law and Human Behaviour, 29, 121-149. http:// dx.doi.org/10.1007/s10979-005-1401-7

Koch, W.J., Douglas, K.S., Nicholls, T.L., \& O’Neill, M. (2005). Psychological injuries: Forensic assessment, treatment and law. Oxford, UK : Oxford University Press. http://dx.doi.org/10.1093/acprof:oso/9780195188288.001.0001

Lange, C., Burgmer, M., Braunheim, M., \& Heuft, G. (2007). Prospective analysis of factors associated with work re-entry in patients with accident-related injuries s10926-006-9039-y, PMid:16838103

Lewis, D. (2009). Assessment for compensation. In V. Roos, \& C. Vorster (Eds.). An introduction to forensic psychology (2nd edn., pp 109-118). Potchefstroom: Platinum Press.

Lowenstein, L.F. (2002). The psychological aspects of personal injuries. Chichester: Barry Rose Law.

Loughead, T.A., Black, D.R., \& DeLucia, J.L. (1989). "Metempsychosis" of caree development. Journal of Career Development, 16, 73-76. http://dx.doi. org/10.1007/BF01354269

Lowman, R.L. (1997). Career assessment and psychological impairment: Integrating inter-domain and work dysfunctions theory. Journal of Career Assessment, 5 , 213-224. http://dx.doi.org/10.1177/106907279700500207
McCarren, M., Janes, G.R., Goldberg, J., Eisen, S.A., True, W.R., \& Henderson, W.G. (1995). A twin study of the association of posttraumatic stress disorder and combat exposure with long term socio-economic status in Vietnam veterans. Journal of Traumatic Stress, 8, 111-124. http://dx.doi.org/10.1002/jts.2490080108, PMid:7712050

Miller, S. (2009). Most employers underestimate health impact on productivity. Human resource magazine, 54, 20.

Nagi, S.Z. (1969). Disability and rehabilitation. Colombus, Ohio: Ohio State University.

Public Administration Leadership and Management Academy (Palama). (2010). Disability management in the Public Service. Pretoria: Government Printer.

Ratzon, N.Z., Ari, E.B., Froom, P., Friedman, S., \& Amit, Y. (2013). Functional capacity evaluation of work performance among individuals with pelvic injuries following motor vehicle accidents. Work, 45, 191-200.

Read, K.M., Kufera, J.A., \& Dischinger, P.C. (2004). Life-altering outcomes after lower extremity injury sustained in motor vehicle crashes. Journal of Traumatic Stress, 57, 815-823. http://dx.doi.org/10.1097/01.TA.0000136289.15303.44

Republic of South Africa. (1998). Employment Equity Act 55 of 1998. Pretoria: Government Printers.

Road Accident Fund. (2010). Road accident fund annual report 2010. Retrieved March 24, 2011, from http://www.raf.co.za/

Road Traffic Management Corporation. (2010). Road traffic management corporation annual report 2010. Retrieved September 5, 2011, from http//www.rtmc.co.za

Rueda, S., Chambers, L.,Wilson, M., Mustard, C., Rourke, S.B., Bayoumi, A., Raboud, J., \& Lavis, J. (2012). Association of returning to work with better health in workingaged adults: a systematic review. American Journal of Public Health, 102, 541556. http://dx.doi.org/10.2105/AJPH.2011.300401, PMid:22390520

Roos, V., \& Vorster, C. (2009). An Introduction to forensic psychology (2nd edn.). Potchefstroom: Platinum Press.

Shults, R.A., Jones, B.H., \& Kresnow, M.J. (2004). Disability among adults injured in motor vehicle crashes in the United States. Journal of Safety Research, 35, 447452. http://dx.doi.org/10.1016/j.jsr.2004.06.001, PMid:15474547

Shaughnessey, J.J., \& Zechmeister, E.B. (2003). Research methods in psychology (4th edn.). New York: McGraw Hill.

Soklaridis, S., Cassidy, J.D., Van der Velde, G., Tompa, E., \& Hogg-Johnson, S. (2012). The economic cost of return to work: An employer's perspective. Work, 43, 255262. PMid:22927610

Spengler, P.M., Blustein, D.L., \& Strohmer, D.C. (1990). Diagnostic and treatment overshadowing of vocational problems by personal problems. Journal of Counseling Psychology, 37, 372-381. http://dx.doi.org/10.1037/0022-0167.37.4.372

Spiegel, M.R., \& Linstrom, D.P. (2000). Statistics. New York: Mc Graw Hill.

Spokane, A.R. (1989). Are there psychological and mental health consequences of difficult career decisions? Journal of Career Development, 16, 19-23. http:// dx.doi.org/10.1177/089484538901600103

Tate, C., \& Pledger, D.G. (2003). Discourse on disability and rehabilitation issues: Opportunities for psychology. Journal for Disability and International Development, 58, 279-284.

Tolin, D.F., \& Foa, E.B. (2006). Sex differences in trauma and posttraumatic stress disorder: a quantitative review of 25 years of research. Psychological Bulletin, 132(6), 959-992, http://dx.doi.org/10.1037/0033-2909.132.6.959, PMid:17073529

United Nations. (2008). United Nations Convention on the Rights of Persons with Disabilities and Optional Protocol.

Vargo, F.E., \& Young, N.D. (2011). What are the signs of learning disabilities? Learning disabilities: A Contemporary Journal, 20, 34-40.

Vogel, A.P., Barker, S.J., Young, A.E., Ruseckaite, R., \& Collie, A. (2011). What is return to work? An investigation into the quantification of return to work. International Occupational Environmental Health, 84, 675-682. http://dx.doi.org/10.1007/ s00420-011-0644-5, PMid:21573769

Wackerly, D.D., Mendenhall, W., \& Scheaffer, R.L. (2008), Mathematical statistics (7th edn.). Wadsworth: Thomson Brooks/Cole.

World Health Organization. (2001). International classification of functioning, disability and health: ICF. Geneva: World Health Organization. 